\title{
Correction to: The Divine Bureaucracy and Disenchantment of Social Life
}

\section{Correction to:}

M. Mohamad, The Divine Bureaucracy and Disenchantment of Social Life, https://doi.org/10.1007/978-981-15-2093-8

The chapters were inadvertently published with incorrect texts which have affected the meaning of the content. These texts have been corrected as below:

Chapter 5, page 179: "It is not true because the contents are full of loving elements, teaching prayers and to get to know Allah pbh (Ia tidak benar kerana pengisiannya penuh dengan elemen kasibsayang, mengajar solat dan mengenal Allah SWT)"

Chapter 5, page 180: Within these two categories, there are also various subcategories of people "hackled and bonded" in accordance to their identity (as "transsexual", "tomboy", "pengkid") or their activities (as in "prostitutes" or "gigolo"), all specified in the fatwa. Zakat allocations are not

The updated versions of these chapters can be found at https://doi.org/10.1007/978-981-15-2093-8_5 https://doi.org/10.1007/978-981-15-2093-8_7 https://doi.org/10.1007/978-981-15-2093-8_8

(C) The Author(s) 2020

M. Mohamad, The Divine Bureaucracy and Disenchantment of Social Life, Contestations in Contemporary Southeast Asia, https://doi.org/10.1007/978-981-15-2093-8_9 
given directly to these groups and individuals but are instead channelled to those (institutions or individuals) who are involved in work and programmes to rehabilitate them.

Chapter 7, page 259: The Penang government had apparently paid RM1.48 million to Maik for the wakafland and planned to build a new surau (community prayer hall) in the mall to replace the old Madrasah Salihiah that was demolished (Star Online 2011).

Chapter 8, page 282: The Malaysian also demonstrates that formerly traditional ulama have been absorbed into the bureaucracy and occupy sinecure positions.

\section{Changed to:}

Chapter 5, page 179: "It is not true because the contents are full of loving elements, teaching prayers and to get to know Allah The Almighty (Ia tidak benar kerana pengisiannya penuh dengan elemen kasih sayang, mengajar solat dan mengenal Allah SWT)"

Chapter 5, page 180: Within these two categories, there are also various subcategories of people "shackled and bonded" in accordance to their identity (as "transsexual", "tomboy", "pengkid") or their activities (as in "prostitutes" or "gigolo"), all specified in the fatwa. Zakat allocations are not given directly to these groups and individuals but are instead channelled to those (institutions or individuals) who are involved in work and programmes to rehabilitate them.

Chapter 7, page 259: The Kedah government had apparently paid RM1.48 million to Maik for the wakafland and planned to build a new surau (community prayer hall) in the mall to replace the old Madrasah Salihiah that was demolished (Star Online 2011).

Chapter 8, page 282: The Malaysian case also demonstrates that formerly traditional ulama have been absorbed into the bureaucracy and occupy sinecure positions. 